\title{
FRANCE'S APPROACH TO THE SYRIA CONFLICT AND THE RUSSIA FACTOR
}

\author{
DOI: 10.20542/2307-1494-2019-1-47-54
}

\begin{abstract}
France's position has been marginalized in Syria, more than eight years after the beginning of the crisis in 2011. Russia's military intervention saved Syrian President Bashar al-Assad from being toppled by his contenders, some of whom have been supported by Paris. At present, whereas the military intensity of the conflict has deescalated, Russia has had the upper hand on the process of the political settlement and, in the meantime, seeks to promote the reconstruction agenda. Paris pays the cost of political choices and an uncompromising posture under the François Hollande administration. Nevertheless, the more realistic and "deideologized" approach of President Emmanuel Macron has so far been able to avoid further tensions with Moscow on the Syrian context. Having few grips on the dynamics of the Syrian crisis, France is left with very few options: to put a high political price for its support in the reconstruction phase and to bet on an eventual clash between Iran and Russia in Syria.
\end{abstract}

Keywords Russia, France, Syria, Turkey, the Kurds, the Middle East, Levant

Название Подход Франции к конфоликту в Сирии и российский фрактор

статьи

Аннотация Спустя восемь лет после начала сирийского конфликта в 2011 г. роль Франции по сирийской проблеме сводится к сугубо второстепенной. Военная интервенция России спасла правящий режим президента Башара аль-Асада от свержения оппозиционными ему силами, часть которых пользовалась поддержкой Парижа. В настоящее время, на фоне снижения интенсивности вооруженного противостояния Россия играет ведущую роль в процессе поиска политического урегулирования и в то же время пытается продвигать повестку, связанную с постконфлликтным восстановлением страны. Маргинализацией своей роли в Сирии Париж расплачивается за политический выбор, сделанный предыдущей французской администрации во главе с Франсуа Олландом, и ее нежелание идти на компромиссы по сирийскому вопросу. Президенту Эммануэлю Макрону, благодаря более реалистичному и деидеологизированному подходу, пока удалось избежать новых трений с Москвой по сирийской проблеме. Для Франции, имеющей ограниченное влияние в сирийских делах, выбор возможных вариантов действия ограничен: либо затребовать высокую политическую цену за свое участие в восстановлении Сирии, либо сделать ставку на столкновение интересов и обострение трений по Сирии между Ираном и Россией.

Ключевые Россия, Франция, Сирия, Турция, курды, Ближний Восток, Левант слова

Igor Delaoë is Deputy-Head, Analytical Center "L'Observatoire", French-Russian Chamber of Commerce, Moscow. Игорь Делануэ - заместитель директора аналитического центра «Обсерво» при Франкороссийской торгово-промышленной палате, Москва. 
Titre d'article Les approches de la France au conflit en Syrie et le facteur russe

Résumé La France se retrouve marginalisée sur le dossier syrien, plus de huit ans après le début du conflit en 2011. L'intervention militaire de la Russie a été un succès dans le sens où elle est parvenue à sauver Bachar el-Assad qui était en passe d'être renversé par ses opposants, dont certains étaient soutenus par Paris. Aujourd'hui, alors que l'intensité militaire du conflit a diminué, la Russie a la main haute sur le processus diplomatico-politique de règlement de la crise et cherche, parallèlement à promouvoir la phase de reconstruction du pays. La France paye le prix de choix politiques et d'une posture intransigeante adoptée sous François Hollande. L'apparente posture réaliste et désidéologisée d'Emmanuel Macron a cependant permis à la France d'aggraver le coût politique de cette approche tout en évitant d'augmenter les tensions avec les Russes. Disposant de bien peu de prises sur la crise syrienne, Paris se retrouve à court d'options; il ne lui reste plus qu'à jouer son va-tout en fixant un prix politique élevé pour son soutien à la phase de reconstruction, et à miser sur une hypothétique rupture entre la Russie et l'Iran en Syrie.

Mots clefs Russie, France, Syrie, Turquie, Kurdes, Moyen-Orient, Levant

\section{Introduction}

France's position has been marginalized in Syria, more than eight years after the beginning of the crisis in March 2011. Russia's military intervention saved President Bashar al-Assad from being toppled by his contenders, some of whom have been supported by Paris. Today, whereas the military intensity of the conflict has deescalated, Russia has the upper hand on the process of the political settlement and, in the meantime, seeks to promote the reconstruction agenda. Being second rank actor on both issues, France has its position been furthermore marginalized by President Donald Trump's decision to withdraw almost all U.S. troops from Syria announced in December 2018. Paris pays the cost of political choices and an uncompromising posture under the François Hollande administration. Nevertheless, deideologized and more realistic approach of Emmanuel Macron has so far been able to avoid further tensions with Moscow in the Syrian context and prevented France from a greater estrangement from the reality of the conflict. Having few grips on the dynamics of the Syrian crisis, France is left with very little options: to put a high political price for its support in the reconstruction phase and to bet on an eventual clash between Iran and Russia in Syria.

\section{The roots of France's policy on the Syria crisis}

From the very beginning of the Syrian crisis in early 2011, France supported the "revolutionary camp", despite early warnings coming from French veteran diplomats that Syria was not Libya and that the ruling regime would hold. Despite these warnings, Paris' posture toward some fractions of the anti-Assad camp has evolved and varied from pure sympathy to full (diplomatic, political and military) support.

France refused to take part in the extension of the U.S.-led operation "Inherent Resolve" to Syria from Iraq since September 2014. Paris found itself in a tricky position: Emmanuel Valls, the French Prime Minister at the time, justified this posture by explaining that, as Paris was seeking the removal of President Assad, striking against terrorists in Syria would indirectly contribute to help him staying in power. Instead, in September 2014, France decided to launch military operation "Chammal" that was strictly 
limited to the Iraqi territory. This approach, nicknamed "neither...nor..." for "neither Assad, nor Daesh", 1 was fiercely advocated by then Minister of Foreign Affairs Laurent Fabius, the staunchest adversary of President Assad inside the French administration.

A year later, in September 2015, President François Hollande eventually decided to extend operation "Chammal" to Syria. He based his decision on the assumption that the terrorists' activities in Syria were on the raise. The French military involvement was as robust as 1100 troops in Iraq (officially none of them were deployed in Syria, although French Special Forces had been already dispatched there, mainly to the Kurdish region), 4 CAESAR self-propelled howitzers (belonging to the French "Wagram" taskforce in action against ISIS ${ }^{2}$ in Iraq), and 10 "Rafales" aircraft deployed at airbases in Jordan (four units) and in the United Arab Emirates (six units). Occasionally, the nuclear aircraft carrier "Charles De Gaulle" was deployed in the Eastern Mediterranean (Levant) - three times between 2014 and 2016 - to reinforce the group.

For France, the overall equation on Syria was tricky and could be summed up as follows: how to fight Daesh without helping Assad. France would not acknowledge at that time its military presence in Syria for at least two reasons: first, because French Special Forces mainly worked with Kurdish militias - the peshmerga - to track and destroy Daesh fighters. From Paris's perspective, it must have been done without harming France's relations with Ankara that has been at odds with the Syrian Kurds from the Democratic Union Party (PYD), the main Kurdish party in Syria. ${ }^{3}$ Secondly, there was no legal basis for the French military intervention in Syria.

Since the beginning of the civil war in Syria to the end of François Hollande's tenure (2012-2017), France demanded President Assad's resignation as a precondition to start political dialogue. Hollande strongly advocated in favor of a military intervention to remove Assad from power, which could nothing but put France at odd with Russia, which had been providing political, diplomatic and logistical support to the Syrian regime even prior to its direct military intervention in the Syrian conflict in late September 2015. Therefore, when Russia's Minister of Foreign Affairs Sergei Lavrov stroke a deal with then U.S. Secretary of State John Kerry to dismantle the Syrian chemical arsenal, helping avoid U.S.-led airstrikes on Syria in September 2013, Paris was terribly disappointed and even found itself somewhat isolated in the "hawkish camp".

It needs to be stressed that since the beginning of the 2010s and the eruption of the "Arab Spring" events across the Middle East, France has been one of the most interventionist Western countries in Middle East developments. In 2011, Paris and London led the campaign against the regime of Muammar Ghaddafi in Libya. In 2013, France was one of the readiest countries to carry out airstrikes ${ }^{4}$ in Syria following the use of chemical weapons, while also adopting the toughest stance during negotiations on the Iran nuclear deal. In either dossier, the French and the Russians did not find themselves on the same page.

Paris kept a bitter taste of Washington's volte-face, but held Moscow responsible for having aborted the military operation against the Syrian regime. Once Russia had successfully entered the Syrian battlefield, it became clear by the end of 2015 or early 2016 that Assad was saved and could not reasonably be toppled by military means. The divergences on the Syrian dossier were so deep (and exacerbated by the Ukraine crisis in the backstage) that even a series of deadly terrorist attacks in Paris in November 2015 were not helpful to France and Russia to find of a common ground in Syria. In late 2016, Moscow led the forces loyal to the regime to the victory in the long battle for Aleppo, in what was extensively depicted by the French media as a bloodshed perpetrated by the Russians and the Syrian regime. The French media coverage of the Aleppo battle was largely emotional, sensationalist and selective. After the Kobané siege in 2014, it was the 
second war fact which benefited from a massive media coverage in France regarding the Syrian conflict. After the battle of Aleppo, the Syrian opposition backed by Paris critically lost political weight. By 2017, France was more marginalized than ever on the Syrian dossier.

\section{Assad stays, so does France}

The battle of Aleppo occurred in the context of the presidential election campaign in France. The Right selected its candidate after painful primaries: François Fillon openly adopted a transgressive posture toward Russia, calling for more discussions with the Kremlin on touchy issues such as Syria and Ukraine. Along with the leader of the Far Right, Marine Le Pen, and the head of the Far Left, Jean-Luc Mélanchon, Fillon was quickly depicted by the press as "pro-Kremlin", or, at best, "Kremlin compatible". His main contender, Emmanuel Macron, adopted a more balanced stance on Russia: neither pro, neither con. On Syria, he made very few comments. This caution provided him, once elected, with greater possibilities to deal with the Kremlin.

Emmanuel Macron's circle of closest foreign and security policy advisers has been more balanced than his predecessor's ${ }^{5}$ and Macron himself has not been known to have any idée fixe on Russia. He received President Vladimir Putin in Versailles in May 2017 to discuss a wide range of bilateral issues. This meeting was seen as an attempt by the newly elected French president to start on sound basis his relation with his Russian counterpart. In June 2017, Macron gave an extensive interview to the European media in which he outlined a pragmatic approach for French diplomacy in the Middle East and North Africa (MENA) region. ${ }^{6}$ He slammed the 2011 intervention in Libya, which created chaos and a failed state. He also emphasized that Paris was no longer demanding that Syrian President Assad steps down as a precondition to starting peace talks with the opposition. This last point toward Assad can be described as a U-turn in the French policy on Syria to the extent that it meant Paris was giving up the ultimate goal of regime change in Damascus.

Trying to "deideologize" France's posture on Syria was part of Macron's wider attempt to reshuffle the French approach to the Middle East and to conflicts and conflict management in that region, including Libya. Paris had three main priorities in the Middle East when Macron came in office: to reassert French influence, eradicate terrorism and cope with the stream of migrants - an issue that politically had undermined not only France, but the EU as a whole. Syria, where Russia is a key military and diplomatic stakeholder, lies somehow at the intersection of all three objectives. However, regarding these three objectives, it is Libya, not Syria, that was set at the top of the French Middle Eastern agenda.

On the one hand, through the establishment of chill and restrained, but operational dialogue with Moscow, Paris was trying to reduce the diplomatic cost of its miscalculation of having called for Assad's ouster (Hollande's mantra "Assad must go") while maintaining its moral posture on the Syrian dossier. On the other hand, Paris learned from the Iranian nuclear agreement inked in July 2015 that France's tough stance during negotiations did not keep French businesses from striking promising deals with Iran afterwards. Therefore, some, around the Elysée Palace, were still tempted to play a similar "hawkish card" in Syria, even as economic opportunities there looked far less promising than in Iran. ${ }^{7}$ More broadly, an enhanced partnership with Moscow regarding Syria would help Paris get back into the diplomatic game while also distancing itself from Washington. Compared with the unpredictability of Donald Trump's foreign policy, Russia's actions in Syria looked far more predictable and consistent to Paris. Moreover, 
in the recent years the White House has been reluctant to recognize any political role for France in Middle Eastern issues, especially concerning the Israeli-Palestinian conflict. From that perspective, a rapprochement with Russia could provide more room for Paris vis-a-vis Washington.

In his June 2017 interview, President Macron announced the creation of a new "contact group" on Syria, an idea that the French later tried to promote, unsuccessfully.

The issue of the use of chemical materials in the Syria conflict has remained a point of contention between Moscow and Paris. Formally, both countries repeatedly declared that any use of chemical weapons has to be firmly punished. However, in Syria, they found themselves several times in opposed camps, accusing each other of manipulation and falsification of reality. During fall 2017, while Russia was promoting its Track Two initiative of the Sochi Congress on Syria, France critically contributed to the creation of the "Group of the Five" involving France, the UK, the United States, Saudi Arabia and Jordan. This forum shared a common view on the chemical issue (by holding Damascus responsible for the alleged occasional use of chemical weapons against its adversaries) and on the mandatory political transition in Syria. The first meeting of the "Group of the Five" was held in Paris in January 2018. This meeting was well-timed to take place a few days before a new round of (unfruitful) peace talks in Vienna and less than a week ahead of the Russia-sponsored Syrian National Dialogue Congress in Sochi. ${ }^{8}$ The Paris meeting could be seen as a new French attempt to regain a diplomatic foothold in Syria after President Macron's failed initiative to create a "Syria contact group" at the United Nations. Besides, France, through this initiative, sought to enhance its diplomatic posture on Syria to appear as a credible stakeholder and, potentially, as an option for Russia, in order to solve politically the Syrian crisis.

However, French-sponsored "Group of the Five" could rather be described as "diplomatic signaling," as it embodies the limits of Paris's diplomatic capacity on the Syrian issue and implicitly acknowledges Russia as the main arbiter of the crisis. Beyond the issue of chemical disarmament, the initiative is likely to remain short-lived, although the group - later known as the "Small Group" - was also joined by Germany and Egypt.

\section{France's moral posture and limited convergence with Russia in Syria}

After two years in office, Emmanuel Macron displayed a pragmatic and realistic stance on the Syrian issue, the chemical weapons issue being a major "red line". However, there have also been very few achievements to build up French posture in Syria, on the one hand, and to enlarge the coordination (not to speak of cooperation) with Russia in the Syrian context, on the other. While Macron, personally, may see the value of talking with the Russians, many people in the politico-military circles in Paris, but also in Moscow, do not share the same opinion. Furthermore, the Elysée Palace remains constrained by Paris's so-called "moral commitments" in the Syrian war. Finally, Libya stays on the top of France's Middle Eastern - North African agenda, since this crisis is closer to the EU and involves potential critical backlashes with the key EU partners such as Italy.

The political settlement in Syria has been stalled since the Sochi Congress was held in January 2018. The Russians have been struggling to settle the Constitutional Committee the parties agreed upon in Sochi. Being very skeptical, if not mistrustful, of the Sochi forum, France was eventually forced to de facto recognize the dynamics created by Moscow around this new format. In September 2018, the Small Group recognized the need to support the creation of the Constitutional Committee, under the auspices of the UN, de facto acknowledging Russia's role as an engine to stimulate the 
political settlement of the eight-year long Syria crisis. ${ }^{9}$ Much like the EU and the United States, France has found itself in the position to live up with the agenda set by Moscow, Teheran and Istanbul in the framework of the Astana process. In this respect, the departure of Staffan de Mistura from his position as the UN special envoy for the settlement of the Syrian crisis in December 2018 and his replacement by the Norwegian Geir Pedersen ${ }^{10}$ have been discreetly welcomed by those in Paris who found de Mistura too complacent with Moscow and the regime in Damascus.

Russia and France see the settlement of the Syrian crisis from different perspectives. If Moscow bets on the return of the Syrian refugees to attract money and the launch the reconstruction phase even in the absence of a formal political settlement, France argues that the political process should be settled first, before any investments can be made in Syria (which also remains under the EU, U.S., UK and other foreign sanctions). However, beyond official posture, France has already acknowledged the fact that Russia scored points with Lebanon and Jordan regarding the issues of Syrian refugees. The reconstruction phase has de facto been launched, although on a limited scale. The real issues for France and French companies are twofold: to participate in the reconstruction of Syria without falling under sanctions, including U.S. unilateral and secondary sanctions, and without complying with Assad's demands. Some in Paris are also tempted to bet on an eventual clash between Russian and Iranian interests in Syria. This would allow France to capitalize upon Russian-Iranian tensions to reinvest in the political side of the Syria conflict management. The extent to which this bet is wishful thinking remains to be seen.

Nevertheless, Paris and Moscow still share a set of common goals in the Levant. Both saw a fair number of their citizens having joined terrorist groups in Syria and Iraq, both oppose the proliferation of weapons of mass destruction across the Middle East, both are willing to fight terrorism and both have supported the Syrian Kurds. However, these convergences should not be overstated, as they do not indicate that France and Russia share the same regional agenda: Paris seeks to regain its influence in the region, whereas Moscow has already achieved this goal following its military intervention in Syria.

Numerous French citizens (nearly 2000) and Russians (around 3400) have joined terrorist groups in Iraq and Syria. The numbers for the post-Soviet space are even more appalling; approximately 8700 people from the former USSR are believed to have joined terrorist groups, putting post-Soviet Eurasia as the largest region of origin of potential recruits for Daesh and other terrorist organizations in the Near East. ${ }^{11}$ This reality poses a clear threat to both Paris and Moscow. Even after President Trump's December 2018 announcement of the U.S. withdrawal from Syria (which remains to be seen) and the eradication of ISIS's territorial core by winter 2019, French Special Forces - around 200 troops as of the early 2019 - are set to stay for the middle term. Their task is to contain the threat posed by French citizens who joined Daesh. In this mission, objectively, they can occasionally, on a case-by-case basis, cooperate with Russian forces, which are basically tasked with the same mission, but regarding the threat posed by Russian citizens or Russian-speakers as "foreign terrorist fighters". Both countries are also committed to identify and, when possible, to bring back their citizens - female and minor family members of ISIS-linked militants - so that they would not be recruited later or used against the interests of their countries of origin. In Russia, one of the lead roles in this sensitive issue has been assigned by the Federal Center to the Chechen Republic and its leader, Ramzan Kadyrov, with a special commission formed to handle the process. ${ }^{12}$ For France, the task is much more difficult in Syria than in Iraq, taking into account that there are no diplomatic relations between Paris and Damascus. Also, until 
early 2019, Paris was not interested in the fate of the French jihadists and their wives and minors jailed in Iraq or held by the Kurds in Syria. However, with the U.S. withdrawal from Syria in sight, Paris took a U-turn on this issue. From early 2019, the French authorities do not exclude any longer the possibility to repatriate the children and their mothers (with their consent) in France, fearing that they could end up in the hands of other groups (or states) and be used against France's interests. As of January 2019, the Syrian Kurds alone were holding 130 French citizens. $^{13}$

The Syrian Kurds have benefited, although to a different extent, from the support from France and Russia. The former has committed limited political support to them and has helped them to fight Daesh, whereas the latter has advocated for more Kurdish autonomy in the framework of the Syrian republic. For Paris, supporting the Kurds came with a price in its relation with Ankara. In April 2018, after Macron hosted a delegation of the PYD in Paris, Ankara disclosed French Special Forces' locations in Syria, ${ }^{14}$ including the Lafarge cement plant. ${ }^{15}$ However, this did not prevent Turkish President Recep Tayyip Erdoğan from inviting President Macron, along with Germany Chancellor Angela Merkel and Russia's President Putin, to Istanbul in October 2018 to discuss the situation in Syria's northern province of Idlib (where most remaining antigovernment militants are concentrated) and the fate of the Syrian refugees. The Istanbul meeting was the first time when France sat at a discussion table about Syria on par with Russia, and this was made possible by Turkey. In return, Paris has supported Turkey's stance on Idlib, i. e., Ankara's opposition to a major Syrian government military offensive there, and on the question of the refugees. In April 2019, President Macron met in Paris with representative of the Syrian Democratic Forces, triggering the wrath of Ankara. ${ }^{16}$ It seems that Paris is using its relations with the Syrian Kurds as a probable bargaining chip with Turkey; since the announcement of the U.S. withdrawal, the likelihood to see any relatively autonomous Kurdish territorial entity in Syria has vanished. This made any promises France could have made to the Kurds seem impossible to hold.

\section{Conclusions}

France's stance on Syria has changed from the sterile uncompromising approach of the Hollande administration to a more flexible and realistic posture adopted by Emmanuel Macron. Yet, the results of this evolution remain to be seen. Macron remains constrained by France's moral commitments, on the one hand, and diplomatic and defense officials and establishment remain reluctant to make any compromises with Russia, let alone with Damascus. However, it is safe to say that divergences on the Syrian dossier have not prevented the French and the Russian military to maintain a fairly good and workable atmosphere with regard to the so-called deconfliction, in and above Syria.

At the same time, beyond the fight against ISIS and some limited convergences on the Kurds (which, however, have not yet been able to produce any cooperation), France and Russia have little in common in the Syrian context. Paris has a limited grip on the dynamic of the dossier. Furthermore, it makes little sense to expect French-Russian cooperation in Syria to gain more traction. The obstacles have more to do with mutual perceptions: Paris thinks Moscow punches above its weight in Syria while Russia only sees France as a useful, but second-rank partner in this crisis. Moreover, from a French perspective, in the broader MENA region, Libya remains far more important than Syria. Yet, France seeks to build up its diplomatic stance on Syria. It is from that perspective that Paris's efforts to maintain the "Small Group" should be viewed. They show France's ability to bring together the Europeans (Germany, the UK), the United States, and some 
Gulf States (Saudi Arabia). With Russia encountering difficulties to deliver results on the Constitutional Committee, Paris wants to be ready to be possibly considered as a valuable diplomatic alternative.

\section{ENDNOTES}

\footnotetext{
1 "Daesh" is the Arabic abbreviation of Islamic State in Iraq and Levant.

2 ISIS - abbreviation for "Islamic State in Iraq and Syria" or "Islamic State in Iraq and ash-Sham" ("ash-Sham" is the Arabic for "Levant").

${ }^{3}$ Turkey considers the PYD as an offshoot of the PKK (Kurdistan Workers' Party).

${ }^{4}$ The UK Parliament had made known that it was not ready to give a "green light" to airstrikes on Syria as early as August 2013.
}

${ }^{5}$ French President Emmanuel Macron is believed to have occasionally consulted Dominique de Villepin and Hubert Vedrine, two former foreign affairs ministers known for their Charles de Gaulleinspired, pragmatic vision of France's foreign policy.

${ }^{6}$ Emmanuel Macron au “Soir”: 'L’Europe n'est pas un supermarché!' // Le Soir. 21 June 2017.

7 This was especially true following U.S. President Trump's decision to ditch the Joint Comprehensive Plan of Action (JCPOA, also known as the Iran nuclear deal) in May 2018.

${ }^{8}$ The Congress was held on 29-30 January 2018.

9 Joint Statement by the Foreign Ministers of the Small Group on Syria, German Federal Foreign Office. Berlin, 27 September 2018. URL: https://www.auswaertiges-amt.de/en/newsroom/news/jointstatement-syria-small-group/2141612.

${ }^{10}$ On 31 October 2018, Geir Pedersen, a veteran Norwegian diplomat, was appointed to the post of the UN Secretary General's Special Envoy for Syria.

${ }^{11}$ Barrett R. Beyond the Caliphate: Foreign Fighters and the Threat of Returnees. The Soufan Center Report, October 2017. P. 10-11.

12 As of April 2019, nearly 50 children of Russian jihadists have returned to Russia and have been resettled in North Caucasia. B руках у антитеррористической коалиции - тысячи женщин и детей боевиков из России // Независимая Газета. 16 апреля 2019.

${ }^{13} 50$ adults and tenth of children. La France pourrait rapatrier les djihadistes français détenus en Syrie // RTS. 30 January 2019.

${ }^{14}$ La Turquie dévoile les implantations des forces spéciales françaises en Syrie // L’Opinion. 3 April 2018.

15 Exclusive: France asked U.S. not to bomb Lafarge factory in Syria in 2014 - emails // Reuters. 25 April 2018.

16 Турция рассердилась на Макрона // Взгляд. 20 апреля 2019 г. 